\title{
Unexpected cause of severe ascending cholangitis in a patient with chronic calculous cholecystitis
}

\author{
Jorge Aguilar-Frasco, Jorge Humberto Rodríguez-Quintero, \\ Paulina Moctezuma-Velázquez, Christopher Ruben-Castillo
}

Department of General Surgery, Instituto Nacional de Ciencias Médicas y Nutrición "Salvador Zubirán", Mexico City, Mexico

Correspondence to Dr Jorge Humberto RodríguezQuintero, huroqu90@gmail.com

Accepted 10 August 2018

\section{DESCRIPTION}

A 46-year-old man with history of type 2 diabetes mellitus and uncomplicated chronic calculous cholecystitis presented to the emergency department with progressive 5-day long right upper quadrant pain which was constant, had an intensity of $8 / 10$, radiated to the right shoulder and associated with nausea, biliary vomit, liquid stools, fever and jaundice.

The patient's family decided to bring him in because of decreased alertness and reactivity. Physical exam revealed abnormal vital signs (with a heart rate of 120 beats/min, respiratory rate of 32 breaths/min, blood pressure of $75 / 42 \mathrm{~mm} \mathrm{Hg}$ and temperature of $35.2^{\circ} \mathrm{C}$ ), decreased alertness (Glasgow Coma Scale score of 13), evident jaundice and pain on palpation over right upper quadrant of the abdomen. Blumberg sign was positive.

Initial arterial blood gas analysis revealed hyperlactataemia of $7 \mathrm{mg} / \mathrm{dL}$ (normal range $0-2 \mathrm{mg} / \mathrm{dL}$ ) suggesting septic shock.

The patient was immediately started on intravenous fluids, vasopressor infusion (norepinephrine $0.06 \mathrm{mcg} / \mathrm{kg} /$ hour) and broad spectrum antibiotics (meropenem/vancomycin). Relevant laboratory tests revealed leucocytosis of $20.5 \times 10^{9}$ (normal range $4-12 \times 10^{9}$ ) with neutrophilia of $90 \%$ (normal range $50 \%-80 \%$ ), elevated C-reactive protein of $29.66 \mathrm{mg} / \mathrm{dL}$ (normal range $0-1.5 \mathrm{mg} / \mathrm{dL}$ ), elevated serum creatinine of $3.2 \mathrm{mg} / \mathrm{dL}$ (normal range $0.5-1.2 \mathrm{mg} / \mathrm{dL}$ ) suggesting acute kidney injury, and a cholestatic pattern on liver function tests with elevated total bilirubin of $3.56 \mathrm{mg} / \mathrm{dL}$ (normal range $0.3-1 \mathrm{mg} / \mathrm{dL}$ ), elevated direct bilirubin of $2.54 \mathrm{mg} /$ $\mathrm{dL}$ (normal range $0.03-0.18 \mathrm{mg} / \mathrm{dL}$ ), elevated alkaline phosphatase of 438 IU/L (normal range 34-104 IU/L), gamma glutamyl transferase of $125 \mathrm{IU} / \mathrm{L}$ (normal range 9-38 IU/L) and moderate transaminasemia with alanine aminotransferase of $236 \mathrm{IU} / \mathrm{L}$ (normal range 7-52 IU/L) and aspartate aminotransferase of $534 \mathrm{IU} / \mathrm{L}$ (normal range 13-39 IU/L). Bedside ultrasonography disclosed indeterminate biliary dilation without an evident site of obstruction. The gallbladder presented lithiasis but no signs of acute cholecystitis.

We suspected the diagnosis of severe acute cholangitis following Tokyo Guidelines criteria (criteria A and B fulfilled). Haemodynamic instability and kidney injury halted the possibility of performing a CT scan with intravenous contrast at this point.

The patient was subjected to endoscopic retrograde cholangiopancreatography (ERCP) aiming for urgent biliary drainage/decompression. ERCP revealed passage of contrast material to the ascending colon (figure 1) and no other pathologic findings. No therapeutic measures were taken during the procedure.
A) Check for updates

(c) BMJ Publishing Group Limited 2018. No commercial re-use. See rights and permissions. Published by BMJ.

To cite: Aguilar-Frasco J, Rodríguez-Quintero $\mathrm{JH}$, Moctezuma-Velázquez $\mathrm{P}$, et al. BMJ Case Rep Published Online First: [please include Day Month Year]. doi:10.1136/bcr-2018 226402

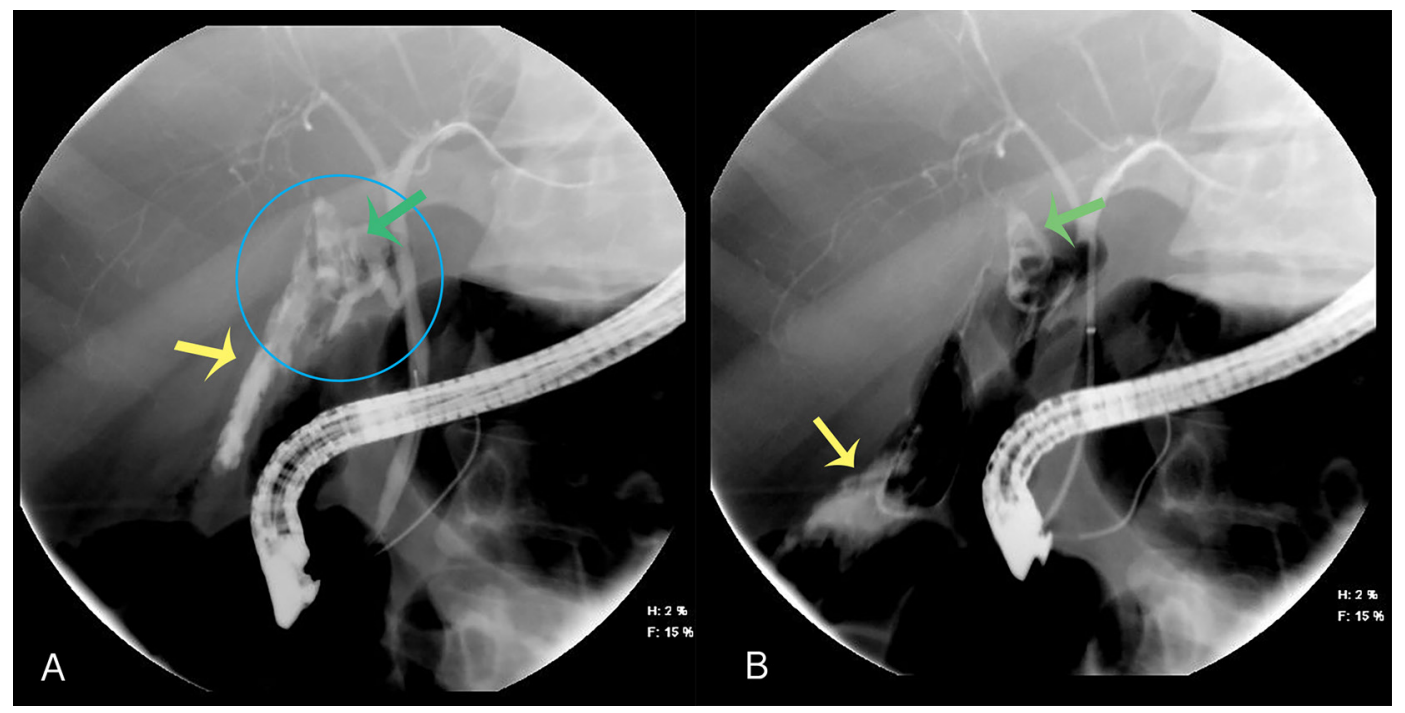

Figure 1 Endoscopic retrograde cholangiopancreatography (ERCP) images. (A) Fistulous tract is shown (blue circle) with passage of contrast material between the gallbladder's (green arrow) infundibulum and ascending colon (yellow arrow). (B) Cholelithiasis is observed (green arrow) as well as advancement of contrast material down the ascending colon (yellow arrow). 


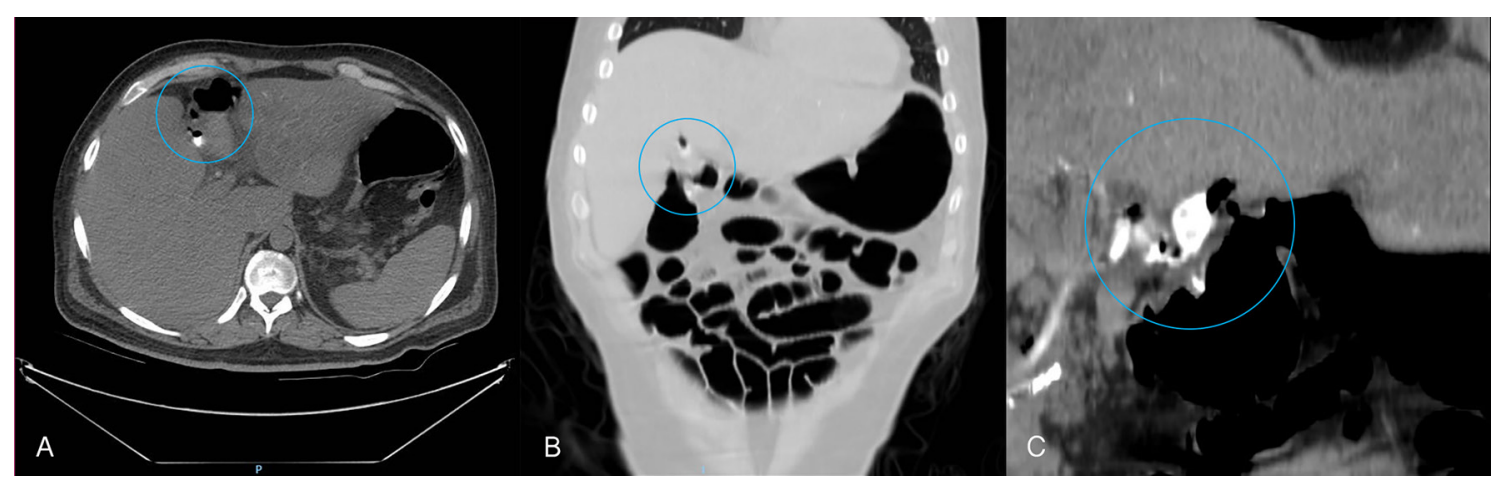

Figure 2 Simple CT scan images showing cholecystocolonic fistula site (blue circle) in axial (A), sagittal (B) and reconstructed (C) views. Note the passage of intrabiliary contrast material and air bubbles from gallbladder to hepatic angle of the colon.

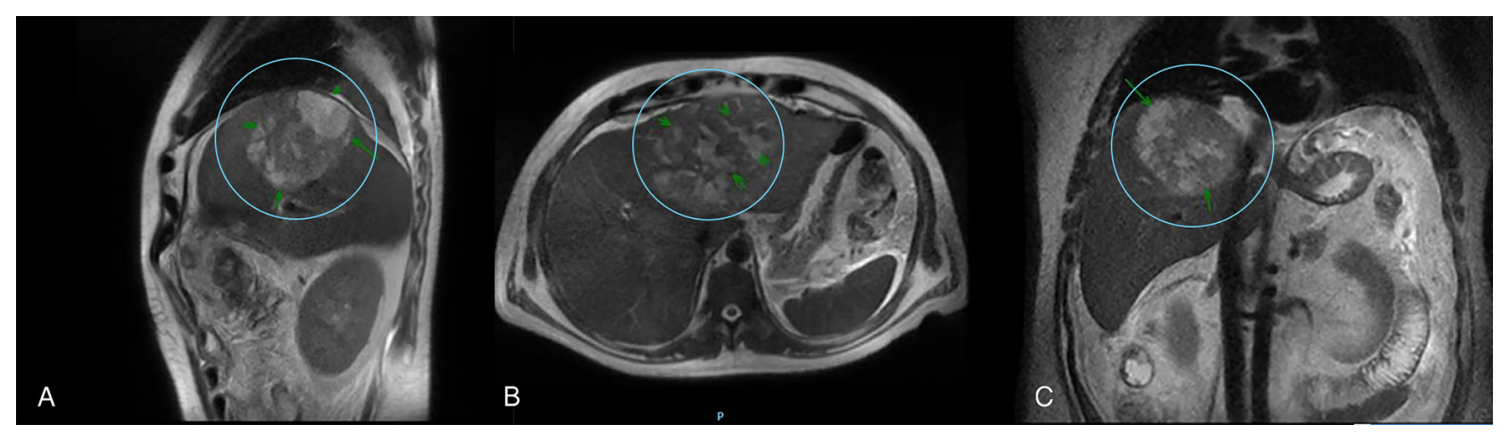

Figure 3 MR images in T2-weighted image (WI) sequence showing the presence of a dominant $5 \times 3 \mathrm{~cm}$ abscess (blue circle) on left liver lobe in sagittal (A), axial (B) and coronal (C) views.

After stabilisation, non-contrast CT revealed evident passage of intrabiliary contrast media (from previous ERCP) and air bubbles from gallbladder's infundibulum to the ascending colon (figure 2).

The patient underwent laparotomy and a subtotal fenestrated cholecystectomy was performed followed by dissection and closure of the fistulous tract with an epiploic patch. The patient presented persistent fever during the postoperatory period, and an MR image was obtained revealing the presence of multiple hepatic abscesses on the left liver lobe, with a single dominant lesion measuring $3 \times 5 \mathrm{~cm}$ (figure 3). A percutaneous catheter was placed to allow for abscess drainage observing full resolution after completion of the antibiotic regime. No recurrences or complications were seen on follow-up.

Cholecystocolonic fistula is an unusual complication of cholelithiasis, occurring in $0.06 \%-0.14 \%$ of such patients. ${ }^{1}$ It is the second most common bilioenteric fistula $(8 \%-26.5 \%$ of

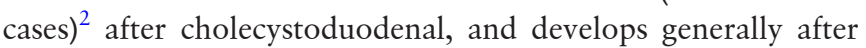
an untreated episode of acute cholecystitis. Bilioenteric fistulas usually manifest clinically as biliary ileum, however this may vary as they may seldom be the underlying cause of ascending cholangitis in patients with no evidence of biliary obstruction or other precipitants, requiring a high index of suspicion for its diagnosis.

Regarding the diagnostic approach, laboratory analysis is non-specific and regular imaging studies will not be able to detect the communication, unless as in our case it is made evident by intrabiliary contrast material. Taking this into consideration, the diagnosis is usually reached after ERCP. Regarding the differential, all other more common causes of ascending cholangitis must be ruled out first in this context.

Failing to detect cholecystocolonic fistulas can lead to recurrent cholangitis and catastrophic consequences during cholecystectomy, increasing the risk of bile duct injury, colonic perforation and faecal peritonitis. Several surgical approaches have been described to treat this condition, including minimally invasive surgery ${ }^{3}$; choosing the most appropriate will depend on the particular presentation and may even require colonic resection and biliary reconstruction when complex fistulas are faced.

\section{Patient's perspective}

Going through this situation was very difficult for me and my family. I never thought that deferring definitive surgical treatment for my already diagnosed condition of biliary stones would put me at risk of going through such a complicated disease.

\section{Learning points}

- Cholecystocolonic fistula is an unusual complication of cholelithiasis.

- It should be considered in patients presenting with ascending cholangitis in the absence of obstruction or other evident precipitants.

- Treatment includes surgical closure of the fistulous tract and will vary depending on the particular characteristics of each case.

Contributors JAF and JHRQ were responsible for planning of the case and conceived the original idea. JAF, JHRQ, PMV and CRC wrote the manuscript. JAF helped supervise and conduct the project. The design of the manuscript was done by JHRQ and PMV. Aquiring of data was achieved by CRC and aquiring and preparing of the images was done by JAF, JHRQ, PMV and CRC. The interpretation of data 
was performed by JAF, JHRQ, PMV and CRC. JAF, JHRQ, PMV and CRC were directly involved in the treatment of the patient.

Funding The authors have not declared a specific grant for this research from any funding agency in the public, commercial or not-for-profit sectors.

Competing interests None declared.

Patient consent Obtained.

Provenance and peer review Not commissioned; externally peer reviewed.

\section{REFERENCES}

1 Balent E, Plackett TP, Lin-Hurtubise K. Cholecystocolonic fistula. Hawaii J Med Public Health 2012;71:155.

2 Costi R, Randone B, Violi V, et al. Cholecystocolonic fistula: facts and myths. A review of the 231 published cases. J Hepatobiliary Pancreat Surg 2009;16:8-18.

3 Chowbey PK, Bandyopadhyay SK, Sharma A, et al. Laparoscopic management of cholecystoenteric fistulas. I Laparoendosc Adv Surg Tech A 2006;16:467-72.

Copyright 2018 BMJ Publishing Group. All rights reserved. For permission to reuse any of this content visit http://group.bmj.com/group/rights-licensing/permissions.

BMJ Case Report Fellows may re-use this article for personal use and teaching without any further permission.

Become a Fellow of BMJ Case Reports today and you can:

- Submit as many cases as you like

Enjoy fast sympathetic peer review and rapid publication of accepted articles

- Access all the published articles

- Re-use any of the published material for personal use and teaching without further permission

For information on Institutional Fellowships contact consortiasales@bmjgroup.com

Visit casereports.bmj.com for more articles like this and to become a Fellow 